\title{
PENERAPAN MODEL PROBLEM BASED LEARNING (PBL) TERHADAP KEMAMPUAN MEMECAHKAN MASALAH DITINJAU DARI PENALARAN SISWA
}

\author{
Ilah Solehati Faudiah ${ }^{1}$, Ilah Nurlaelah ${ }^{2)}$, Ina Setiawati ${ }^{3)}$ \\ ${ }^{1}$ Mahasiswa Program Studi Pendidikan Biologi FKIP, Universitas Kuningan \\ Email: ilahsolehati2016@gmail.com \\ ${ }^{2}$ Dosen Program Studi Pendidikan Biologi FKIP, Universitas Kuningan \\ Email: ilah.nurlaelah@uniku.ac.id \\ Email: ina.setiawati@uniku.ac.id
}

APA Citation: Faudiah, I.S., Nurlaelah, I., \& Setiawati, I. (2018). Penerapan Model Problem Based Learning (PBL) Terhadap Kemampuan Memecahkan Masalah Ditinjau Dari Penalaran Siswa. Quagga: Jurnal Pendidikan dan Biologi, 10(1), 41-46. doi: 10.25134/quagga.v10i01.920.

\begin{abstract}
Abstrak:Penelitian ini bertujuan untuk menganalisis penerapan model problem based learning (PBL) terhadap kemampuan memecahkan masalah ditinjau daripenalaran siswa. Metode penelitian yang digunakan adalah Quasi Eksperimental Design. Pengambilan sampel dilakukan dengan menggunakan teknik Cluster Random sampling. Instrumen dalam penelitian ini adalah test penalaran siswa, test uraian, assesment kinerja, self assesment, lembar observasi dan angket siswa. Uji hipotesis dengan menggunakan uji $t$, korelasi dan analisis regresi sederhana untuk menelaah pengaruh model PBL terhadap kemampuan memecahkan masalah ditinjau dari penalaran siswa, didapatkan Thitung 1150 lebih besar dari Ttabel 2,655 yang artinya ada pengaruh kemampuan memecahkan masalah siswa yang menerapkan model PBL dengan yang tidak menerapkan model PBL, serta 0,93 nilai korelasi dan regresi 0,92. Sehingga kemampuan penalaran siswa berpengaruh terhadap kemampuan memecahkan masalah siswa.
\end{abstract}

Kata Kunci: Model Problem Based Learning (PBL), Kemampuan MemecahkanMasalah, Kemampuan Penalaran

\begin{abstract}
This study aimed to analyze the influence of the model of Problem BasedLearning (PBL) on problem-solving skills in terms of student reasoning. Themethod used was Quasi-Experimental Design. Sampling was conducted using cluster random sampling technique. Instruments in this study is the test ofreasoning of students, test descriptions, performance assessment, self-assessment, observation sheets and questionnaires students. Hypothesis test using $t$ test, correlation and simple regression analysis to examine the influence of PBL model on problem solving abilities in terms of students' reasoning, obtained Thit 1150 is bigger than Ttab 2,655 which means there is influence of problem solving ability of student applying PBL model with that do not apply PBL model, and 0,93 correlation and regression value 0,92. So that students' reasoning ability has an effect on student problem solving ability.

Keywords: ModelsProblem Based Learning(PBL), Ability Problem Solvingskills, Reasoning Ability
\end{abstract}

\section{PENDAHULUAN}

Kemampuan memecahkan masalah merupakan kemampuan berpikir tingkat tinggi yang perlu dikembangkan dalam pembelajaran agar peserta didik dapat mengikuti kemajuan IPTEK yang semakin pesat. Kemampuan memecahkan masalah adalah salah satu kompetensi yang harus dikuasai siswa pada setiap jenjang sekolah. Kemampuan memecahkan masalah dapat dilatihkan oleh guru melalui penerapan model pembelajaran salah satunya yaitu model
Problem Based Learning (PBL). Hal ini sejalan dengan pernyataan Hamruni, (2009) bahwa model Problem BasedLearning (PBL) adalah suatu pendekatan pembelajaran yang dimulai dengan menyelesaikan suatu masalah, tetapi untuk menyelesaikan masalah itu peserta didik memerlukan pengetahuan baru untuk dapat menyelesaikannya. PBL melibatkan peserta didik dalam proses pembelajaran secara aktif dan kolaboratif, serta berpusat kepada siswa, sehingga siswa mampu mengembangkan kemampuan 
Quagga: Jurnal Pendidikan dan Biologi Volume 10, Nomor 1, Januari 2018

memecahkan masalah secara mandiri (Suyadi, 2013).

Arends (2008) menyatakan bahwa Problem Based Learning (PBL) adalah model pembelajaran dengan pendekatan pembelajaran pada masalah autentik dan bermakna kepada siswa, dalam penggunaannya untuk mendukung pemikiran tingkat tinggi dalam situasi berorientasi masalah. Model ini bercirikan penggunaan masalah dalam kehidupan nyata sebagai sesuatu yang harus dipelajari siswa untuk melatih kemampuan memecahkan masalah serta memungkinkan siswa untuk memahami konsep bukan hanya sekedar menghafal konsep (Wasiso, 2013).

Kemampuan memecahkan masalah sangat berkaitan erat dengan kemampuan penalaran siswa karena dalam proses pemecahan masalah akan muncul berbagai pertanyaan sehingga akan terjadinya proses berpikir atau penalaran. Penalaran sebagai kegiatan berpikir mempunyai ciri tertentu yang sangat terkait dengan karakteristik biologi yakni adanya pola berpikir logis dan sifat analitis. Berpikir logis berarti berpikir menurut logika dan sifat analitik menunjukkan bahwa penalaran merupakan kegiatan berpikir yang menyandarkan diri pada suatu analisis. Maka jika penalaran siswa baik kemungkinan kemampuan memecahkan masalah juga baik (Nathalie, dkk, 2015).

Materi yang dipelajari adalah Sistem Ekskresi. Konsep tersebut sangat relevan untuk melatih kemampuan memecahkan masalah, karena pada materi sistem ekskresi khususnya subpokok proses dan kelainan sistem ekskresi pada kulit, ginjal, hati dan paru-paru memaparkan beberapa permasalahankontekstual, yaitu membahas kelainan-kelainan yang terjadi dalam kehidupan sehari-hari. Penerapan yang menggunakan permasalahan berhubungan dengan kehidupan sehari-hari akan memfasilitasi dan mendorong siswauntuk melatih kemampuan memecahkan masalah. Sehingga materi sistem ekskresi cocok dengan menggunakan model Problem BasedLearning (PBL)
p-ISSN 1907-3089, e-ISSN 2651-5869

https://journal.uniku.ac.id/index.php/quagga

\section{METODOLOGI PENELITIAN}

Metode penelitian yang digunakan dalam penelitian ini adalah metode Quasi eksperimen, sedangkan desain yang digunakan dalam penelitian yaitu posttest onlygroup design (Sugiyono, 2014).

Penelitian dilaksanakan pada semester genap tahun ajaran 2016/2017, yaitu dari bulan april-mei 2017. Populasi yang diambil dalam penelitian ini adalah siswa kelas XI IPA 1 dan 2 SMA Negeri tahun ajaran 2016/2017 yang berjumlah 69 siswa. Teknik pengambilan sampel yang digunakan dalam penelitian ini adalah cluster random sampling, penulis memilih sampel penelitian sehingga dapat 2 kelas dengan jumlah 69 yaitu 34 siswa ( Kelas XI IPA 1) kelas eksperimen yang menggunakan model Problem Based Learning dan 35 siswa (Kelas XI IPA 2) kelas kontrol mengunakan metode Inquiri Terbimbing.

Instrumen dalam penelitian ini adalah test penalaran siswa, test uraian kemampuan kemampuan memecahkan masalah, assesment kinerja, self assesment, lembar observasi dan angket siswa.

\section{HASIL DAN PEMBAHASAN}

Hasil posttest kemampuan memecahkan masalah kelas eksperimen dan kelas kontrol secara keseluruhan dianalisis secara deskriptif berdasarkan rubrik penilaian kemampuan memecahkan masalah yang disesuaikan dengan indikator kemampuan memecahkan masalah. Hasil analisis juga dapat dijadikan sebagai patokan sebagai kriteria atau tingkatan kemampuan memecahkan masalah. Hasil keterampilan memecahkan masalah Tiap indikator disajikan pada gambar 1 sebagai berikut:

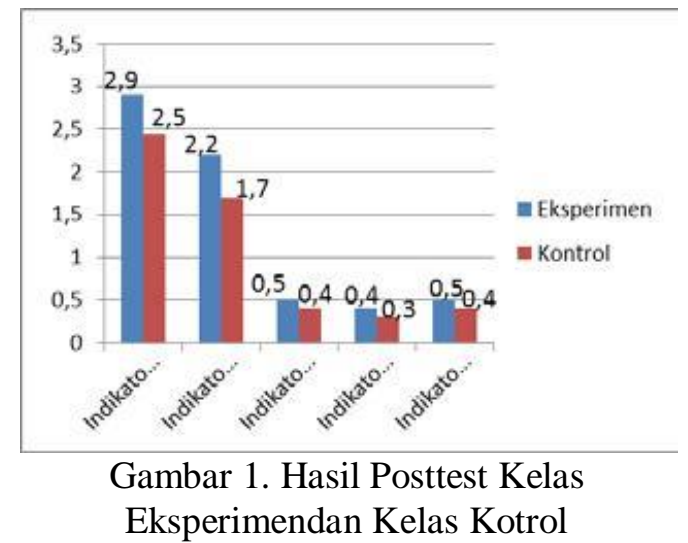


Quagga: Jurnal Pendidikan dan Biologi Volume 10, Nomor 1, Januari 2018

Hasil kemampuan memecahkan masalah kelas eksperimen lebih besar dibandingkan kelas kontrol hal ini disebabkan model PBL yang diterapkan pada kelas eksperimen karena model PBL mempersiapkan siswa pada situasi investigasi untuk memecahkan suatu permasalahan yang terdapat dalam kehidupan sehari-hari. Model pembelajaran ini memberikan siswa kesempatan yang luas untuk melakukan penyelidikan, karena didalam model PBL siswa dilibatkan secara aktif dalam memecahkan masalah dan berpikir lebih tinggi (Chine, Christie et $a l, 2005)$.

Hasil nilai rata-rata posttest pada kelompok penalaran atas dan bawah kelas eksperimen dapat dilihat sebagai berikut:

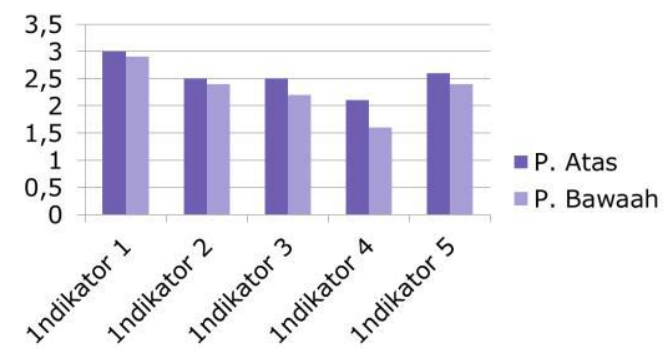

Gambar 2. Hasil nilai rata -rata posttest pada kelompok penalaran atas dan bawah kelas eksperimen

Berdasarkan gambar 2 dapat dilihat bahwa nilai rata-rata kemampuan memecahkan masalahkelas eksperimen kelompok penalaran atas lebih besar dibandingkan dengan kelompok penalaran bawah.

Hasil nilai rata-rata posttest pada kelompok penalaran atas dan bawah kelas kontrol dapat dilihat sebagai berikut:

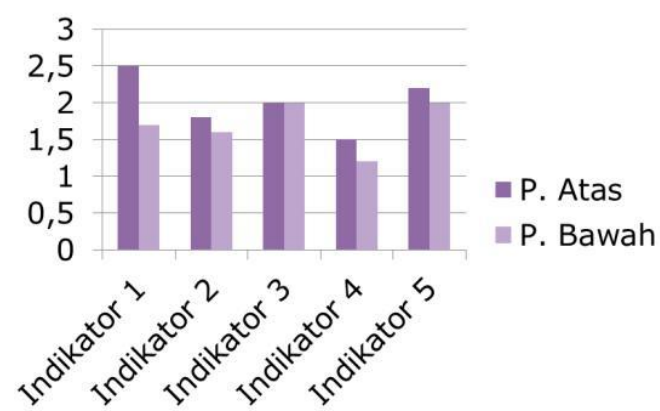

Gambar 3. Hasil nilai rata -rata posttest pada kelompok penalaran atas dan bawah kelas kontrol
p-ISSN 1907-3089, e-ISSN 2651-5869

https://journal.uniku.ac.id/index.php/quagga

Berdasarkan gambar 3 dapat dilihat bahwa nilai rata-rata kemampuan memecahkan masalah kelas kontrol kelompok penalaran atas lebih besar dibandingkan dengan kelompok penalaran bawah.

Hal ini dapat disimpulkan bahwa siswa yang memiliki penalaran tinggi kemampuan memecahkan masalahnya baik dan siswa yang mememiliki penalaran rendah kemampuan memecahkan masalahnya kurang baik dikarenakan penalaran merupakan pengaplikasian pengetahuan dalam konteks pemecahan masalah.

Untuk menjawab hipotesis penelitian, dilakukan analisis data dengan uji normalitas, homogenitas, dilanjutkan uji t, korelasi dan regresi. Tabel analisis statistik dapat di lihat sebagai berikut:

Tabel 1. Hasil Uji Statistika Tes

\begin{tabular}{cccc}
\multirow{2}{*}{ Uji Statistik } & \multicolumn{3}{c}{ KemampuanMemecahkan } \\
& \multicolumn{3}{c}{ Masalah } \\
\cline { 2 - 4 } & hit & tab & Kesimpulan \\
\hline $\begin{array}{c}\text { Uji } \\
\text { Normalitas }\end{array}$ & 10,12 & 11,3 & Normal \\
\hline $\begin{array}{c}\text { Uji } \\
\text { Homogenitas }\end{array}$ & 1,03 & 2,26 & Homogen \\
\hline Uji t & 1150 & 2,65 & $\begin{array}{c}\text { Hipotesis } \\
\text { Diterima }\end{array}$ \\
\hline $\begin{array}{c}\text { Korelasi } \\
\text { Regresi }\end{array}$ & 0,93 & & $\begin{array}{c}\text { Signifikan } \\
\text { Signifikan }\end{array}$ \\
\hline
\end{tabular}

Hasil uji t menujukkan bahwa thit $1150>$ ttab 2,65 maka H0 ditolak dan H1 diterima, hipotesis diterima artinya terdapat perbedaan kemampuan memecahkan masalah pada kelas eksperimen dan kelas kontrol ditinjau dari penalaran siswa.

Sehingga terjadi peningkatan kemampuan memecahkan masalah yang menggunakan model PBL dengan yang tidak menggunakan PBL, kemudian kemampuan penalaran siswa juga berpengaruh terhadap kemampuan memecahkan masalah. Penerapan model PBL dapat memfasilitasi siswa dalam memecahkan masalah karena setiap fase PBL terdapat indikator kemampuan memecahkan masalah. Hal ini sejalan menurut Chin, Christine et al, 2005 bahwa pembelajaran dengan menggunakan model Problem Based Learning (PBL) sangat efektif untuk melatih 
Quagga: Jurnal Pendidikan dan Biologi Volume 10, Nomor 1, Januari 2018

kemampuan memecahkan masalah dan memfasilitasi siswa untuk bisa memecahkan permasalahan yang ill-stucture.

Model Problem Based Learning (PBL) yang diterapkan pada kelas eksperimen ini memiliki tahapan-tahapan yangdapat digunakan untuk melatih kemampuan memecahkan masalah, kemampuan bernalar, karena didalam karakteristik model Problem Based Learning (PBL) salah satunya yaitu kegiatan penyelidikan, sehingga siswa berperan aktif dalam proses pembelajaran di kelas. PBL dapat memungkinkan siswa untuk memahami sains dengan baik karena PBL merupakan metode alternatif untuk meningkatkan kemampuan memecahkan masalah siswa Agraw et al (2017).

Keterlaksanaan dalam model PBL dalam dilihat dari hasil lembar observasi. Rekapitulasi dari hasil lembar observasi penerapan model PBL dapat dilihat pada Gambar 4 berikut:

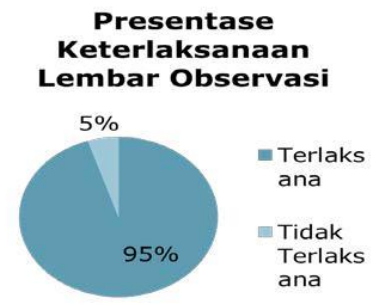

Gambar 4. Lembar Observasi

Dari gambar 4 terlihat bahwa keterlaksanaan langkah-langkah dalam penerapan model PBL dengan kemampuan memecahkan masalah dapat terlaksana dengan baik.

Hasil asesment kinerja dapat dilihat pada gambar 5 sebagai berikut:

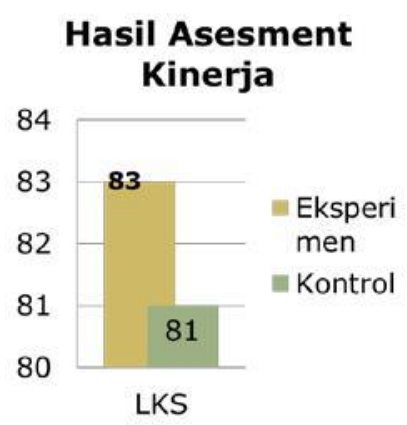

Gambar 5. Hasil Asesmen kinerja

Berdasarkan hasil Asesmen kinerja pada saat mengerjakan Lembar Kerja Siswa diperoleh hasil kelas eksperimen lebih tinggi
p-ISSN 1907-3089, e-ISSN 2651-5869

https://journal.uniku.ac.id/index.php/quagga

dibandingkan pada kelas kontrol karena pada kelas eksperimen menggunakan model PBL siswa harus merumuskan masalah, menganalisis, mencari informasi, dan mencari solusi secara mandiri, sedangkan pada kelas kontrol cenderung pasif karena rumusan masalahnya telah diberikan oleh guru.

Hasil Self Asesment Kerja tim PBL dapat dilihat pada gambar 6 yaitu sebagai berikut:

\section{Self Assesment Kerja Tim PBL}

- P. Atas P.Bawah

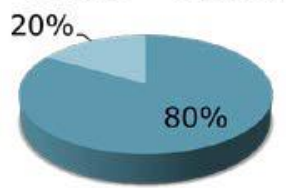

Gambar 6. Hasil Self Asesment

Berdasarkan hasil self asesment pertanyaan kerja tim PBLyang hanya diberikan pada kelas eksperimen dapat disimpulkan bahwa mereka menyukai pembelajaran menggunakan model PBL.

Lembar angket digunakan untuk mengetahui respon siswa terhadap model PBL. Hasil lembar angket respon siswa terhadap model pembelajaran PBL dapat dilihat pada Gambar 7 berikut :

\section{Presentase} Angket Siswa

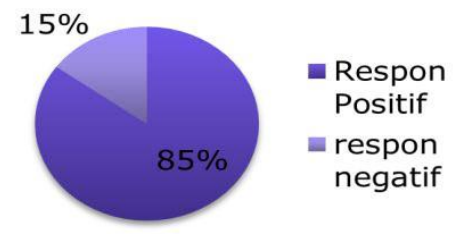

Gambar 7. Hasil angket siswa

Berdasarkan hasil dari setiap butir pernyataan diperoleh presentase lebih dari $65 \%$ yang menunjukkan bahwa dari setiap pernyataan tersebut respon siswa setuju. Sehingga dapat disimpulkan bahwa penerapan model PBL dapat memberikan respon positif dengan membuat siswa menjadi aktif dalam proses pembelajaran, memudahkan siswa untuk memahami materi, meningkatkan keterampilan memecahkan masalah sehingga 
Quagga: Jurnal Pendidikan dan Biologi Volume 10, Nomor 1, Januari 2018

siswa dapat memecahkan permasalahan dengan sendirinya.

Kemampuan memecahkan suatu masalah pada dasarnya merupakan tujuan utama dari proses pendidikan, katena dengan mencapai pemecahan suatu masalah secara nyata, siswa juga mencapai suatu kemampuan baru dalam perilaku berfikir atau bernalar (Feriesha, 2014). Kemudian Marzano, 2008 mengemukakan bahwa bernalar merupakan pengaplikasian pengetahuan dalam konteks pemecahan masalah. Sehingga kemampuan memecahkan masalah sangat berkaitan erat dengan kemampuan penalaran siswa karena dalam proses pemecahan masalah akan muncul berbagai pertanyaan sehingga akan terjadinya proses berpikir atau penalaran.

Hal ini sejalan dengan Komala (2017) yang mengemukakan bahwa penerapan model PBL dapat meningkatkan kemampuan bernalar siswa, karena PBL mengharuskan siswa untuk melakukan investigasi autentik yang berusaha menemukan solusi riil, dimana siswa harus menganalisis dan menetapkan masalahnya,mengembangkan hipotesis dan membuat prediksi, mengumpulkan dan menganalisis prediksi dan menarik. Siswa dituntut untuk mengembangkan keterampilan berpikir, menyelesaikan masalah, dan bernalar ketika proses pembelajaran. Sehingga dapat disimpulkan bahwa siswa yang memiliki penalaran atas memiliki kemampuan memecahkan masalah yang baik sedangkan siswa yang dengan kemampuan penalaran bawah cenderung kurang baik dalam memecahkan permasalahan. Hal ini disebabkan karena siswa dengan penalaran atas akan lebih aktif dalam melakukan kegiatan yang menuntut kreativitas kemampuan memecahkan masalah siswa sehingga siswa lebih bersemangat dalam kegiatan pembelajaran. Sedangkan siswa dengan penalaran bawah siswa cenderung pasif dalam kegiatan pembelajaran Rini,dkk (2014)

\section{KESIMPULAN}

Berdasarkan hasil penelitian yang telah dilakukan oleh peneliti, dapat disimpulkan bahwa penerapan model Problem Based Learning (PBL) dapat meningkatkan kemampuan memecahkan masalah siswa, hal ini dikarenakan fase-fase PBL dapat
p-ISSN 1907-3089, e-ISSN 2651-5869

https://journal.uniku.ac.id/index.php/quagga

memfasilitasi siswa dalam memecahkan masalah seperti; mengidentifikasi masalah, menghasilkan gagasan, merencanakan langkah, menerapkan dan mengevaluasi proses pemecahan masalah.

\section{REFERENSI}

Agraw, Awake Shishigu. et al. 2017. The Effect of Problem Based Learning (PBL) Instruction on Students' Motivation band Problem Solving Skills of Physics. [Online]. EURASIA Journal of Matematics Science and Technology Education. ISSN: 1305-8223. P-1305-8215 Volume13 No 3. Tersedia: www.iorsjournals.org. Diakses pada Tanggal 30 juni 2017

Arends, I Richard.2008. Learning to Teach. (diterjemahkan oleh: Helly dan Sri). Yogyakarta: Pustaka Pelajar.

Chin, Cristine and Li-Gek Chia.2005. Problem Based Learning: Using illSctructured Problems in Biology Project [Online]. Wiley Periodicals. Tersedia

:www.interscience.wiley.com.

Diakses pada Tanggal 3 juni 2017

Feriesha, Lathu Anjani. 2014. Implementasi Model Pembelajaran Heuristik Vee

Berbasis Kerangka Intruksional Marzano Untuk Meningkatkan Kemampuan Memecahkan Masalah. Skripsi FKIP UNIKU. Tidak diterbitkan

Hamruni. 2009. Strategi danModel-model Pembelajaran Aktif Menyenangkan. Jakarta: BumiAksara

Herman, Tatang. 2007. Pembelajaran Berbasis MasalahUntuk Meningkatkan Kemampuan

Penalaran Matematis Siswa SMP (Online), Jurnal Cakrawala Pendidikan. ISSN: 190-8838, Volume 1 , Tersedia: http://eprints.uny.ac.id/398/1/pembel ajaran_berbasis_masalah.pdf.Diakses pada Tanggal 12 Februari 2017

Komala Tita Riani, Nurlaelah Ilah dan Setiawati Ina. 2017. Peningkatan Kemampuan Penalaran Siswa Melalui Model Problem Based Learning (PBL) ditinjau Dari Kemampuan 
Quagga: Jurnal Pendidikan dan Biologi Volume 10, Nomor 1, Januari 2018

Akademik di SMA. [Online]. Jurnal Quagga vol 9 No.1 Januari 2017, Tersedia https://journal.uniku.ac.id/index.php/ quagga/article/view/516

Mann, Anne Elcan. 1982. The Effects of a Problem-Solving Strategy on the Long-Term Memory of Algorithms. UNF Theses and Dissertations. Paper 16. Tersedia: http://digitalcommons.unf.edu/etd/16 Marzano,Robert J. dan Jonh S. Kendall. 2008. Designing And Assesing Education Objectives, Applying The New Taxonomy. : Library of Congress Cataloging-in-Publication.

Nathalia, Inten. et al. 2015. Pengaruh Model Pembelajaran Berbasis Proyek Terhadap Hasil Belajar Matematika Ditinjau dari Kemampuan Penalaran Operasional Konkret (Online), $e$ Journal PGSD Universitas Pendidikan Ganesha Jurusan PGSD Volume: 3 No: 1(Diakses pada tanggal 29 Januari 2017)

Rini, Juwita. Budiyono. Imam, Sujadi. 2014. Eksperimentasi Model Pembelajaran Berbasis Masalah dan Problem Posing pada Materi Bangun Ruang Datar Ditinjau dari Kemampuan Penalaran siswa kelas VIII SMP Negeri di kabupaten Banyumas Tahun Pelajaran 2013/2014 [Online]. Jurnal Elektronik Pembelajaran Matematika .Vol.2 no. 8. ISSN: 2339-1685. Tersedia: http://jurnal.fkip.uns.ac.id. Diakses pada Tanggal 16 mei 2017
p-ISSN 1907-3089, e-ISSN 2651-5869

https://journal.uniku.ac.id/index.php/quagga

Sugiyono. (2014). MetodologiPenelitian Kuantitatif, Kualitatif, danR \& D . Bandung:Alfabeta

Suyadi. 2013. Strategi Pembelajaran Pendidikan Karakter.Bandung : Remaja Rosdakarya.

Wasiso, \& Hartono. 2013. Implementasi Model Problem BasedLearning Bervisi sets untuk Meningkatkan Kemampuan Pemecahkan Masalah dan kebencanaan oleh siswa. Journal ofInnovative Science Education. 